\title{
Institutional Investors, Political Connections and Analyst Following in Malaysia
}

\begin{abstract}
We examine the association between institutional ownership, political connections, and analyst following in Malaysia from 1999 to 2009. Based on 940 firm-year observations, we document a positive relation between institutional ownership, particularly by Employees Provident Fund (EPF), and analyst following, thus supporting the governance role that institutional investors play in promoting corporate transparency. However, there is no evidence that political connections matter to analyst following. The monitoring role of institutional investors, including EPF, does not appear to be any different between politically connected and nonconnected firms.
\end{abstract}

Keywords: Institutional Investors; Analyst Following, Corporate Governance, Political Connections; Malaysia

JEL classifications: G32, G34 


\subsection{Introduction}

Financial analysts play an important intermediary role in the capital market by providing information about firms, including estimates of earnings and price forecasts and buy/sell recommendations (Healy \& Palepu, 2001). Analysts’ services are also demanded by external parties to assist in monitoring (Jensen \& Meckling, 1976; Brown et al., 2011) and valuing the firms (Bradshaw, 2011). Bushman and Smith (2001) and Healy and Palepu (2001) find lower information asymmetry for firms with greater analyst following, suggesting that analysts provide an important contribution to the firm's information environment (Bushman et al., 2004).

Studies that examine the determinants of analyst following have centred on firm characteristics, including institutional ownership (O’Brien \& Bhushan, 1990; Hussain, 2000; Ackert \& Athanaskos, 2000, 2003; Fernando et al., 2012) and corporate governance (Baik et al., 2010; Yu, 2010) as well as the rules and regulations of the capital market (Tan et al., 2011). However, nothing is known about how analyst following is related to political connections. Our first aim in this paper is to fill this void by providing the first evidence on the association between political connections and analyst following in Malaysia.

The intimate ties between the business elites and political leaders are an integral part of many economies, particularly the emerging economies, including Malaysia. In Malaysia, almost one-third of the listed firms are known to be politically connected (Faccio et al., 2006). The extant evidence shows that politically connected firms are highly opaque, and that there is greater information asymmetry between the connected firms and market participants, such as financial analysts. The opacity is due in part to the higher complexity and uncertainty of the income generation process created by the connection (Chen et al., 2011). The protection that government provides to connected firms, e.g., government bailouts (Faccio et al., 2006) and the imposition of tariffs on competitors (Goldman et al., 2013), allows managers of these firms 
to practise greater discretion on financial disclosure thus further contributing to firm opacity (Bhattacharya et al., 2003). Indeed, Chaney et al. (2011) find that the quality of accounting information is significantly poorer for politically-connected firms, and Lim et al. (2014) report that these firms have a less timely price discovery process. Riahi-Belkaoui (2004) finds managers in connected firms camouflage their performance, increasing earnings opacity. All these studies suggest that connected firms have a poorer information environment. As analysts are attracted to firms with more informative disclosure policies (Lang \& Lundholm, 1996), we thus predict that there is a negative relation between political connections and the number of analysts following the firms. Since connected firms receive preferential treatment from governments ${ }^{1}$ and are thus less reliant on external funding (Faccio et al., 2006), analysts also have less incentive to forecast the earnings of these firms.

Our second aim is to examine the association between institutional ownership and analyst following. Institutional investors have substantial market power, influence, and sophistication in gathering and interpreting information about the firm (Grier \& Zychowicz, 1994; Abdul Wahab et al., 2007). These attributes provide institutional investors considerable advantage in monitoring corporate activities compared to other investors. Karpoff (2001) finds that institutional investors are successful in shareholder activism, prompting firms to act in accordance with investors' needs. Aggarwal et al. (2011) find a positive relation between institutional ownership and corporate governance in a cross-country study. Some supporting evidence of this in Malaysia is provided by Abdul Wahab et al. (2008).

The effectiveness of institutional investors as a monitoring body has been recognized by governments that incorporate institutional monitoring duties into regulations in order to ensure

\footnotetext{
1 These preferential treatment include easy access to cheaper bank loans (Chaney, Faccio \& Parsley, 2011; Claessens, Feijen \& Laeven, 2008; Leuz \& Oberholzer-Gee, 2006; Johnson \& Mitton, 2003; Khwaja \& Mian, 2005); the awarding of profitable government contracts (Goldman, Rocholl \& So, 2013; Bertrand, Kramarz, Schoar \& Thesmar, 2007; Wu, Wu \& Rui, 2012); and lower taxation (Bertrand, Kramarz, Schoar \& Thesmar, 2007; Faccio, 2010).
} 
adequate oversight (Starks, 2000). In Malaysia, the Finance Committee in Corporate Governance (FCCG) highlighted the need for greater involvement by institutional investors in corporate governance after the 1998 Asian financial crisis. This has resulted in the establishment of the Minority Shareholders Watchdog Group (MSWG), which aims to protect the interest of minority shareholders through shareholder activism and acts as an independent research organization to advise and encourage good governance practices amongst publicly listed firms (MSWG, 2010). There are four founding members of MSWG, ${ }^{2}$ which collectively dominate the market share of institutional investments in Malaysia (Abdul Wahab et al., 2007). Ammer and Abdul Rahman (2009) investigate the effectiveness of shareholder activism by MSWG, and find that MSWG-targeted firms earn higher stock returns than non-targeted firms in the long run. They note that the two most important issues raised by MSWG during annual meetings are financial reporting and corporate governance. Domestic institutional investors can thus provide effective monitoring of corporate behaviour (Chhaochharia et al., 2011).

We argue that financial institutions are able to mitigate information asymmetry by pressuring firms to disclose information. Since institutional investors play an important governance role by promoting corporate transparency, we thus predict that firms with higher institutional ownership have greater analyst following, all else equal. Further, in performing their fiduciary duties (Hawley and Williams, 1997), institutional investors are likely to demand for analyst services to help them assess the potential investee firms (O’ Brien \& Bhushan, 1990; Shleifer and Vishny, 1997; Hussain, 2000; Jennings, 2005). This suggests it is more profitable for analysts to follow firms with higher institutional shareholdings. Thus, analyst following is expected to be higher for these firms.

\footnotetext{
2 The four founding members of MSWG are the Permodalan Nasional Berhad (PNB), Lembaga Tabung Angkatan Tentera (LTAT), Social Security Organisation (SOCSO), and Pilgrim Fund Board (LUTH).
} 
The effectiveness of institutional investors as monitors of politically connected firms is less clear. One the one hand, the presence of institutional investors in connected firms is expected to promote better reporting environment and increase corporate transparency, thus attracting greater analyst following. However, in Malaysia, government proxies sit on the advisory board of MSWG members. Political involvement in firms' decision making suggests that MSWG investment is likely to be dictated by the government. In an attempt to enhance Bumiputera shareholdings in the capital market under the New Economic Policy (NEP), ${ }^{3}$ these domestic institutional investors are likely to skew their investment toward connected firms rather than firms with better governance. The presence of institutional investors in connected firms may thus be politically driven rather than for governance purposes. This argument predicts that the relation between analyst following and institutional ownership is attenuated in politically connected firms.

Based on a sample of 940 firm-year observations from 1999 to 2009, we find some evidence of a positive relation between institutional ownership and analyst following. This supports the corporate governance argument that institutional investors demand greater information disclosure, thus attracting more analysts to the firm. We extend the analysis to reflect the heterogeneity in institutional investors in Malaysia, and find that the ownership of Employees Provident Fund (EPF), the largest institutional investor in Malaysia, is an important determinant of analyst following. Specifically, firms with a higher EPF shareholding have significantly greater analyst following. This result is consistent with the significant participatory role played by EPF in corporate governance (Abdul Wahab et al., 2007). However, MSWG shareholdings are not significant in explaining analyst following.

\footnotetext{
${ }^{3}$ The New Economic Policy (NEP) was a social re-engineering and affirmative action program formulated by the National Operation Council in the aftermath of the 1969 racial riot in Malaysia. NEP was adopted in 1971 for a period of 20 years and ucceeded by the National Development Policy (NDP) in 1991. The main objective of NEP (and its successor, NDP) is to achieve national unity by eradicating poverty, irrespective of race, and by restructuring the society to achieve inter-ethnic economic parity between Bumiputera and non-Bumiputera (Gomez and Jomo, 1999). Its second objective is to reduce inter-ethnic economic differences.
} 
Despite the strong and well-documented presence of political connections in Malaysia (Johnson and Mitton, 2003; Faccio et al., 2006), we find no evidence that political connection is an important determinant of analyst following. The monitoring role of institutional investors, including EPF, does not appear to be any different between politically connected and nonconnected firms.

Our paper contributes in the following ways. First, it contributes to the increasing volume of research that has capitalized on the political economy of Malaysia (Gomez \& Jomo, 1999; Johnson \& Mitton, 2003; Adhikari et al., 2006; Gul, 2006; Fraser et al., 2006; Abdul Wahab et al., 2007; Bliss \& Gul, 2012a, 2012b) by showing whether a firm is politically connected matters to analysts' decision to follow the firm. Second, we add to the literature on the heterogeneity in institutional shareholders by showing the type of institutional monitoring in Malaysia that matters to analyst following. Our findings have important implications for other countries in the neighbouring region where strong government intervention is a salient feature of the capital markets, and which can substantially affect the information environment for investors.

The rest of paper is set as follows. Section 2 provides a background discussion of political connections and institutional investors in Malaysia. Section 3 outlines our research design, and Section 4 describes the data. Results are discussed in Section 5, and Section 6 concludes the paper.

\subsection{Background}

\subsection{Political Connections}

Selznick (1949) argues that political connections exist due to uncertainty of government regulations, and lead to firms working together with the government. Theories forwarded by North (1990) and Olson (1993) suggest that the connection provides government with a means 
of controlling the firms so that they will act in congruence with the government's agenda. Politicians have been known to extract rents generated by these connections (Shleifer \& Vishny, 1994), ${ }^{4}$ and in return, the connected firms would receive preferential treatment such as precedence over government contracts.

The growth in research interest on political connections in Malaysia has largely spun from the work of Gomez and Jomo (1999). Subsequent studies utilise their data on political connections and provide valuable insights into the various roles of political connections in Malaysia, e.g., Johnson and Mitton (2003) on capital control, Adhikari et al. (2006) on effective tax rates, Gul (2006) on audit fees, Fraser et al. (2006) on leverage, Abdul Wahab et al. (2007) on corporate governance, and Bliss and Gul (2012a, 2012b) on leverage and cost of debt respectively. Cross countries studies such as Bushman et al. (2004) and Faccio et al. (2006) have also examined political connections in Malaysia in relation to transparency and other characteristics of connected firms. We add to this line of research by investigating political connections in relation to analyst following.

\subsection{Institutional Investors}

The purpose of the three government bodies in Malaysia, namely departmental agencies, statutory bodies, and government owned firms, is to accelerate Bumiputera participation in employment, education, and the corporate sector, in particular (Gomez \& Jomo, 1999). The latter is achieved through a restructuring of equity participation where foreign equity is to be reduced from 60 to 30 percent, Bumiputera equity raised from practically zero to 30 percent, and Chinese and Indian equity maintained at 40 percent (Norhashim \& Abdul Aziz, 2005). Based on data gathered from various Malaysian Plans, we report that Bumiputera share 
ownership has increased from a mere 1.5 percent in 1969 to 21.9 percent in 2008 (Appendix A).

Subsequent to the establishment of NEP, it is an "open secret" that the domestic institutional investors in Malaysia provide government the vehicle to enhance and protect the economic interests of Bumiputera investors. Domestic institutional investors are run by Bumiputera who typically hold the position of the Chair of the board of directors. Appointments to the Investment Advisory Board for the top five domestic institutional investors in Malaysia, namely EPF, PNB, LTH, LTAT, and SOCSO, are politically motivated (Norhashim \& Abdul Aziz, 2005) as the Board reports directly to the Ministry of Finance (Asher, 2001). It is worth noting that investments of these institutional investors are heavily biased towards Bumiputera-run corporations (Norhashim \& Abdul Aziz, 2005). A point in case is the gradual takeover of Malaysian Airline System (MAS) from Naluri Berhad by two main government-run institutional investors, Kumpulan Wang Amanah Pencen (KWAP) and Bank Simpanan Nasional (BSN), in 2001. Although this may be construed as a pure political bailout, others may see this takeover as an important national obligation as there were speculations of a foreign takeover of MAS.

Foreign institutions, mostly pension funds, make up a negligible fraction $(\sim 1 \%)$ of institutional investors in the Malaysian capital market. Among them are California Public Employees’ Retirement System (CALPERS), Teachers Insurance and Annuity Association College Retirement Equities Fund (TIAA-CREF), United Nation Pension Funds, and State of Ohio Retirement Scheme.

Since the Asian financial crisis, the role of institutional investors in Malaysia has changed dramatically in that they are now expected to play a much bigger role in the capital market, not only to facilitate the government objectives, but also to enhance good governance in firms. Recent evidence suggests that the relation between institutional ownership, particularly by 
$\mathrm{EPF}$, and corporate governance has strengthened subsequent to the corporate governance reform in 2001 (Abdul Wahab et al., 2007), in line with the lead role taken by the EPF in establishing MSWG.

\subsection{Research Design}

To test the research aims, we run the following regression model:

$$
\begin{aligned}
& \text { Ln(Analyst_Following })_{i t}=a_{0} \text { Constant }_{i t}+a_{1} \text { Institutional_Ownership }{ }_{i t}+ \\
& a_{2} \text { Political_Connection }{ }_{i t}+a_{3}\left(\text { Political_Connection } \times \text { Institutional_Ownership) }{ }_{i t}{ }^{+}\right. \\
& a_{4} \text { Forecast_Error }_{i t}+a_{5} X \_ \text {Listed }_{i t}+a_{6} 1 \text { Price }_{i t}+a_{7} \text { Size }_{i t}+a_{8} \text { Duality }{ }_{i t}+ \\
& a_{9} \text { Board_Independence }{ }_{i t}+a_{10} \text { Management_Ownership }{ }_{i t}+\text { Industry }_{i t}+\text { Period }_{i t}+\text { error }_{i t} \text {, }
\end{aligned}
$$

where the dependent variable (Ln(Analyst_Following) is the natural log transformation of the number of analysts following a firm. Our independent variables of interest are Institutional_Ownership, Political_Connection, and their interaction.

Institutional_Ownership is measured by the percentage ownership of the top five institutional investors in a firm, consistent with Hartzell and Starks (2002) and Abdul Wahab et al. (2008). Since institutional investors are known to have different goals and adopt different ways to achieve these goals (Brickley et al., 1988, Bushee et al., 2009), ${ }^{5}$ we construct three additional institutional ownership variables to capture institutional investor heterogeneity in Malaysia. Mintchik et al. (2011) and Chan et al. (2013) provide evidence that the heterogeneity in institutional investors matters to the properties of analyst forecasts; transient investors are drawn to firms with lower forecast errors.

\footnotetext{
${ }^{5}$ Bushee et al. (2009) employs trading behaviour to assign institutional investors into three distinct groups. The first is transient investors which are institutions with high portfolio turnover and high diversification. The second group is dedicated investors which are institutions that are characterised by low portfolio turnover and concentrated ownership. The final group, quasi-indexer are characterised by diversified portfolio and low portfolio turnover.
} 
We first compute MSWG, which constitutes the cumulative shareholdings of the four founding domestic members of MSWG. For the second alternative institutional ownership variable, we single out the shareholding of $E P F$ as it is the largest pension fund in the country. The sheer size of EPF suggests that it has the resources to influence the governance structure of its investee firms, which should lead to better financial disclosure. Abdul Wahab et al., (2007) report the relation between EPF shareholding and corporate governance has strengthened subsequent to the corporate governance reform in 2001. The third variable is OTHERS, which consists of the cumulative institutional shareholdings that do not fall into MSWG and EPF.

Political_Connection takes the value of 1 if the firm is politically connected and zero otherwise. A firm is defined to be politically connected if at least one of its large shareholders or top officers is a member of parliament, a minister, or is closely related to a top politician or a party (Faccio et al., 2006). We extend the list of politically connected firms developed by Johnson and Mitton (2003) to include firms controlled by Khazanah Berhad ${ }^{6}$ and those identified by Gul et al. (2010). Appendix B provides the list of politically connected firms in our sample.

We control for a number of variables in the tests. Following Lang and Lundholm (1996), Lang et al. (2004), and Yu (2010), we control for earnings surprise since analyst following is expected to be lower for firms with greater earnings surprise. Earnings surprise (Forecast_Error) is proxied by the absolute difference between the analyst forecast of earnings per share (EPS) and actual EPS scaled by share price. Cross-listed firms are subject to greater disclosure requirements and are thus expected to be associated with greater analyst following

\footnotetext{
${ }^{6}$ Khazanah Nasional Berhad is the investment holding arm of the Government of Malaysia entrusted to hold and manage the commercial assets of the government and to undertake strategic investments. Khazanah was incorporated under the Companies Act 1965 on 3 September 1993 as a public limited company. The share capital of Khazanah is owned by the Minister of Finance, a body corporate incorporated pursuant to the Minister of Finance (Incorporation) Act, 1957.
} 
(Chen \& Steiner, 2000). We control for cross-listed firms by assigning a value of one to $X \_L i s t e d$ if the firm is also listed in a foreign exchange and zero otherwise. The inverse of share price (1/Price) is included in the regression as Brennan and Hughes (1991) find it to be negatively related to analyst coverage. Financial analysts tend to follow larger firms which have the potential to generate more business for them (Ackert \& Athanassakos, 2003; Bradshaw, 2011). Larger firms also have a richer information environment which further attracts analyst following. We control for firm size using the natural log transformation of market capitalization as at the end of the financial year (Size).

Corporate governance quality is also controlled for in the test. Arguments for a positive relation between corporate governance and analyst following reside on the premise that good governance promotes corporate disclosure (Fan \& Wong, 2002). This in turn lowers the analyst's cost of providing an earnings forecast and thus incentivize the analyst to follow the firm (Yu, 2010). Conversely, Healy and Palepu (2001) and Jiraporn et al. (2008) regard analyst coverage as a substitute for corporate governance. Good governance in this case lessens the usefulness of the analyst report so that better governed firms with a richer information environment attract fewer analysts. We utilise three corporate governance variables that reflect the board structure. The first is Duality, which takes a value of one if the CEO and Chairman positions are held by the same person and zero otherwise. The second is board independence (Board_Independence), measured by the proportion of independent directors on the board. The third governance mechanism that we control for is managerial ownership (Management_Ownership). Potential expropriation by managers is higher in firms with lower managerial ownership as the interests between managers and shareholders are less aligned in these firms.

Finally, we control for industry sectors. Moyer et al. (1989) argue that some industries are affected by regulatory bodies or legal regulations and constraints, and that the regulatory 
bodies which oversee these sectors may reduce investors' demand for external financial analysis by acting as a substitute to monitoring. We include year dummies to control for unobserved time effects, including changes in macroeconomic conditions occurring during the sample period.

\subsection{Data}

Our sample comprises non-financial firms listed on Bursa Malaysia for the period 1999 to 2009. Data on institutional ownership, managerial ownership, Bumiputera directors, and various governance variables are collected from annual reports sourced from the Bursa Malaysia’s website, and Compustat Global and Mergent Online databases. We then merge this sample with the sample of firms with data on analyst following from I/B/E/S database. This procedure results in a final sample of 940 firm-year observations.

Panel A of Table 1 shows that the average number of analysts following a firm is 6.21 , close to the figure reported by Yu (2010). The average (median) institutional ownership is 16.88 (11.71) percent, and ranges from zero to 94.37 percent. The average (median) shareholding of the largest domestic institutional investor, $E P F$, is 5.31 (3.32) percent, and that of the MSWG members stands at 6.66 (2.27) percent. Institutional investors in the OTHERS group include state-owned funds, insurance firms, trusts, and foreign institutional investors, and collectively, their average (median) shareholding is 4.89 (0.73) percent. About 28 percent of our sample firms are politically connected.

Panel B shows that the market capitalization (Size) of sample firms averages RM 2.433 billion and has a median of RM 614 million. The average (median) absolute forecast error is 67.8 (16.8) percent of share price, and ranges from zero to 2000 percent. Only 6.3 percent of sample firms are cross-listed. Looking at the governance variables, the average (median) proportion of independent directors on the board is 36.58 (33.33), consistent with the 
governance code which recommends that at least one third of the board should consist of independent directors. About 35.20 percent of the firms have Duality where the CEO and Chairman functions are held by the same person. The average and median managerial ownership are 5.51 and 0.20 percent respectively, with a maximum of 95.73 percent.

\section{\{Table 1 here\}}

\subsection{Results}

Table 2 provides both Pearson and Spearman-rank correlations between variables. As expected, the correlation between Institutional_Ownership and Ln(Analyst_Following) is $0.192(p<0.01)$ and $0.234(p<0.01)$ for Pearson and Spearman-rank respectively. Therefore, there is some preliminary support for the prediction that analyst following is greater for firms with higher institutional ownership. Firm size is positively and significantly correlated with institutional ownership and analyst following, suggesting that larger firms have greater analyst following and higher institutional shareholding. There is also a positive and significant correlation between the political connection variable and institutional ownership and analyst following.

\{Table 2 here

In Table 3, we segregate the firms into those with "high" and "low" analyst following using the sample median $(\mathrm{N}=3)$ as the cut-off. Results show that firms with high analyst following have significantly higher institutional ownership and are larger in size. This finding is consistent with the monitoring role of institutional investors in enhancing corporate disclosure, and the greater transparency of larger firms. The univariate tests show that firms with high analyst following are also more likely to be politically connected (POLCON) and cross-listed (X_Listed), and have lower managerial ownership.

\{Table 3 here 
We regress analyst following on its determinants in Table 4, which reports the results for various specification models. In specification (1), we include only the control variables. Both the institutional ownership and political connection variables are added in specification (2), and their interaction is added in specification (3).

Results show a positive and significant relation between institutional ownership and analyst following $(0.004, t=1.713)$ in specification (2). A one standard deviation increase in institutional ownership increases the number of analyst following by one. Hence, consistent with our prediction and Bhushan (1989) and O’Brien and Bhushan (1990), firms with higher institutional ownership attract greater analyst following. This finding thus supports the argument that institutional investors play an important governance role by ensuring more informative corporate disclosure policies.

\{Table 4 here $\}$

Contrary to expectations, we find a negative but insignificant coefficient for Political_Connection, suggesting that analyst following for politically connected firms is indistinguishable from that of other firms. One possible explanation for this is that the connected firms have the biggest slice of domestic institutional investments, which are mostly controlled by the government. In other words, the relation between political connection and analyst following is attenuated by institutional ownership. We test this in specification (3). However, the results show that the interaction term Political_Connection $\times$ Institutional_Ownership is also insignificant. Of the set of control variables, we find that analyst following is positively related to firm size and the inverse of share price (I/Price), but negatively related to earnings surprises.

In Table 5, we consider the heterogeneity of institutional investors in Malaysia. Specifications (1), (3), and (5) report the results for EPF, MSWG, and OTHERS respectively. In specifications (2), (4), and (6), we include the interaction term between each of these 
heterogeneous groups of institutional investors and the political connection dummy. Results show that there is a significantly positive coefficient only for EPF. Therefore, unlike the other groups of institutional investors, firms that have higher shareholdings by EPF have greater analyst following. Our results thus hint on the effectiveness of EPF in enhancing corporate governance (Abdul Wahab et al., 2007) and more specifically corporate transparency, which helps to attract more analysts to the firms. The interaction variable EPF $\times$ Political_Connection (specification (2)) is insignificant, suggesting that EPF plays a similar role in politically connected firms.

There is some evidence that politically connected firms have less analyst following, as shown in specification (2), consistent with the notion that connected firms are more opaque. None of the interaction terms are significant. The results for the control variables are as before, with firm size, the inverse of price, and earnings surprise remaining significant in explaining analyst following.

\{Table 5 here\}

\subsection{Robustness: Endogeneity}

The relation between analyst following and institutional ownership may be subject to simultaneity bias since firms with higher analyst following are also likely to attract more institutional investors. O’Brien and Bhushan (1990) argue that analysts' decision to follow a firm and financial institutions' decision to invest in the firm are jointly determined through demand and supply considerations of brokerage (which employ analysts) and institutional investors. That is, analysts are motivated to follow firms with larger institutional holdings because of the fee that they can get for providing services to the institutions. At the same time, institutions are attracted by the marketing of brokerages’ services and therefore are likely to 
invest more heavily in firms that are followed extensively by analysts (O'Brien and Bhushan, 1990; Hussain, 2000).

Our study employs an instrumental variable (IV) in a two-stage least squares (2SLS) regression to address this potential simultaneity bias. We use Bumiputera directors, return on assets (ROA), leverage, and systematic risk as the instruments for the suspect endogenous variable, the percentage of institutional ownership.

The establishment of NEP and its successor NDP is to promote Bumiputera shareholdings in the capital market. Among the initiatives of the NEP is the establishment of Bumiputera-friendly institutions such as PNB, EPF, LTAT, and LTH, which are expected to skew their investment towards firms with Bumiputera directors. Having more Bumiputera directors on the board is thus an important determinant of institutional shareholdings. The presence of Bumiputera directors is a unique institutional feature of the Malaysian market and is not likely to directly influence the number analysts following the firm, except potentially through institutional ownership. Firm performance provides another instrument since institutional investors are likely to be attracted to firms with good performance, but is not directly related to analyst following. We use the return on assets $(R O A)$ calculated over the period of five years to proxy for firm performance. Similarly, leverage and systematic risk are likely to affect institutional ownership (as a substitute monitoring mechanism) but not analyst following. Leverage is total debt to total assets, and systematic risk (Beta) is computed using the market model on the last 250 days of stock returns.

We control for corporate governance. Bushee and Noe (2000) explain why corporate disclosure, as a dimension of corporate governance, is an important determinant of institutional ownership. First, institutional investors may be attracted to better governed firms with greater information disclosure if such disclosure reduces the price impact of trades. Second, institutional investors may be sensitive to corporate disclosure practices if such disclosures 
influence the potential for profitable trading opportunities. Third, corporate disclosure practices may be important to institutions if they rely on public disclosure for corporate governance activities. Chung and Zhang (2011) argue that institutional investors prefer firms with better governance for fiduciary responsibilities, lower monitoring costs, and liquidity reasons. They find institutional shareholding increases with governance quality. We also control for Managerial_Ownership and Size since managerial ownership can act as a governance mechanism in mitigating agency conflicts (Morck et al., 1988; Short \& Keasey, 1999), thus attracting more institutional investment in the firms, and institutional investors have been known to hold a larger stake in larger firms (Gillan \& Starks, 2003).

Results from the 2SLS equations are presented in Table 6. From the first-stage regressions, it is evident that the percentage of Bumiputera directors is a predictor of institutional investor ownership. However, the (partial) $F$ statistic ${ }^{7}$ is 7.193 for Institutional_Ownership, suggesting that the instruments are somewhat weak. We examine the validity of the instrument by computing the overidentification statistic, ${ }^{8}$ which is chi-square $\left(X^{2}\right)$ distributed with degrees of freedom equal to the difference between the number of instruments and the number of endogenous variables. The statistic shows the instruments used for Institutional_Ownership are identified. Finally, the Hausman test does not reject the null of no endogeneity. This highlights the importance of addressing the endogeneity of institutional ownership, and indicates a preference for 2SLS estimates over that of OLS.

The results from the second-stage regressions are consistent with the OLS results, and show an insignificant relation between Institutional_Ownership and In(Analyst_Following).

\footnotetext{
${ }^{7}$ We employ the F statistics benchmark figure suggested by Stock et al. (2002) which are: 1= 8.96, $2=11.59,3$ $=12.83,5=15.09$, and $10=20.88$.

${ }^{8}$ The Sargan statistics can be obtained by a regression of the second-stage residuals on all exogenous variables. If the instruments are valid, the coefficients on the instruments should be close to zero. The formal test is based on the $R^{2}$ from this model being close to zero. In particular, $(n-m) * R^{2}$ is distributed $\chi^{2}$ with K-L degrees of freedom, where $\mathrm{K}$ is the number of exogenous variables unique to the first-stage and $\mathrm{L}$ is the number of endogenous explanatory variables. " $n$ " is the number of observations while $m$ is the number of variables in the OLS regression. Note that this test requires that at least one of the instruments is valid (i.e., exogenous).
} 
This result remains insignificant when the interaction term Political_Connection $x$ Institutional_Ownership is included in the test, as shown in specification (4).

\{Table 6 here $\}$

\subsection{Conclusion}

We investigate whether institutional ownership and political connection are important drivers of analyst following in Malaysia, where political involvement in corporate decisions is a salient feature of the capital market. Our sample consists of 940 firm-year observations during the period 1999-2009. Despite the well documented preferential treatment and protection that governments provide to politically connected firms in Malaysia, we do not find any difference in analyst following between connected and non-connected firms.

Consistent with our prediction, we find some evidence of positive relation between institutional ownership and analyst following. Therefore, institutional investors seem to provide an important corporate governance mechanism by enhancing corporate disclosure policies, and this attracts more financial analysts to follow the firms. In examining the heterogeneity of institutional investors in Malaysia, we find that the relation between institutional ownership and analyst following is driven by EPF. However, the monitoring role of institutional investors, including EPF, does not appear to be any different between politically connected and non-connected firms. Our results are robust to tests of potential endogeniety between institutional ownership and analyst following. 


\section{References}

Abdul Wahab, E. A., How, J., \& Verhoeven, P. (2007). The Impact of the Malaysian Code on Corporate Governance: Compliance, Institutional Investors and Stock Performance. Journal of Contemporary Accounting \& Economics, 3(2), 106-129.

Abdul Wahab, E. A., How, J., \& Verhoeven, P. (2008). Corporate Governance and Institutional Investors: Evidence from Malaysia. Asian Academy of Management Journal of Accounting and Finance, 4(2), 67-90.

Ackert, L. F., \& Athanassakos, G. (2000). Institutional Investors, Analyst Following, and the January Anomaly. Journal of Business Finance \& Accounting, 27(3/4), 469-485.

Ackert, L. F., \& Athanassakos, G. (2003). A Simultaneous Equation Analysis of Analysts' Forecast Bias, Analyst Following and Institutional Ownership. Journal of Business Finance and Accounting, 30(7), 1017-1041.

Adhikari, A., Derashid, C., \& Zhang, H. (2006). Public Policy, Political Connections, and Effective Tax Rates: Longitudinal Evidence from Malaysia. Journal of Accounting and Public Policy, 25(5), 574-595.

Aggarwal, R., Erel, I., Ferreira, M., \& Matos, P. (2011). Does Governance Travel Around The World? Evidence from Institutional Investors. Journal of Financial Economics, 100(1), 154181.

Ammer, R., \& Abdul Rahman, R. (2009). The Impact of Minority Shareholder Watchdog Group Activism on the Performance of Targeted Firms in Malaysia Asian Academy of Management Journal of Accounting and Finance, 5(1), 67-92.

Asher, M. G. (2001). Pension Reform, Capital Markets and Corporate Governance in Malaysia. Journal of Financial Regulation and Compliance, 9(1), 30-37.

Baik, B. O. K., Kang, J.-K., \& Morton, R. (2010). Why Are Analysts Less Likely to Follow Firms with High Managerial Ownership? Journal of Accounting, Auditing \& Finance, 25(2), 171-200.

Bertrand, M., Kramarz, F., Schoar, A., \& Thesmar, D. (2007). Politicians, Firms and the Political Business Cycle: Evidence from France.

Bhattacharya, U., Daouk, H., \& Welker, M. (2003). The World Price of Earnings Opacity. The Accounting Review, 78(3), 641-678.

Bhushan, R. (1989). Firm Characteristics and Analyst Following. Journal of Accounting and Economics, 11(2-3), 255-274.

Bliss, M. A., \& Gul, F. A. (2012a). Political Connection and Cost of Debt: Some Malaysian Evidence. Journal of Banking \& Finance, 36(5), 1520-1527.

Bliss, M. A., \& Gul, F. A. (2012b). Political Connection and Leverage: Some Malaysian Evidence. Journal of Banking \& Finance, 36(8), 2344-2350. 
Bradshaw, M. T. (2011). Analysts Forecasts: What do we know after Decades of Work? SSRN eLibrary.

Brennan, M. J., \& Hughes, P. J. (1991). Stock Prices and the Supply of Information. The Journal of Finance, 46(5), 1665-1691.

Brickley, J. A., Lease, R. C., \& Clifford W.Smith, J. (1988). Ownership Structure and Voting on Antitakeover Amendments. Journal of Financial Economics, 20, 267-291.

Brown, P., Beekes, W., \& Verhoeven, P. (2011). Corporate Governance, Accounting and Finance: A Review. Accounting \& Finance, 51(1), 96-172.

Bushee, B., Carter, M. E., \& Gerakos, J. (2009). Institutional Investor Preferences for Corporate Governance Mechanisms. Available at SSRN 1070168.

Bushee, B., \& Noe, C. (2000). Corporate Disclosure Practices, Institutional Investors and Stock Return Volatility. Journal of Accounting Research, 38(Supplement), 171-202.

Bushman, R., Piotroski, J., \& Smith, A. (2004). What Determines Corporate Transparency? Journal of Accounting Research, 42(2), 207-252.

Bushman, R. M., \& Smith, A. J. (2001). Financial Accounting Information and Corporate Governance. Journal of Accounting and Economics, 32(1-3), 237-333.

Chan, K. C., Zhang, F., \& Zhang, W. (2013). Analyst Coverage and Types of Institutional Investors. Review of Accounting and Finance, 12(1), 60-80.

Chaney, P. K., Faccio, M., \& Parsley, D. (2011). The Quality of Accounting Information in Politically Connected Firms. Journal of Accounting and Economics, 51(1-2), 58-76.

Chen, C. J., Ding, Y., \& Kim, C. F. (2011). High-level Politically Connected Firms, Corruption, and Analyst Forecast Accuracy Around the World. Journal of International Business Studies, $41,1505-1524$.

Chen, C. R., \& Steiner, T. L. (2000). Tobin's Q, Managerial Ownership, and Analyst Coverage: A Nonlinear Simultaneous Equations Model. Journal of Economics and Business, 52(4), 365382.

Chhaochharia, V., Kumar, A., \& Niessen- Ruenzi, A. (2012). Local Investors and Corporate Governance. Journal of Accounting and Economics, 54(1), 42-67.

Chung, R., Firth, M., \& Kim, J.-B. (2002). Institutional Monitoring and Opportunistic Earnings Management. Journal of Corporate Finance, 8(1), 29-48.

Chung, K. H., \& Zhang, H. (2011). Corporate Governance and Institutional Ownership. Journal of Financial \& Quantitative Analysis, 46(1), 247-273.

Claessens, S., Djankov, S., \& Lang, L. H. P. (2000). The Separation of Ownership and Control in East Asia Corporations. Journal of Financial Economics, 58(1-2), 81-112. 
Claessens, S., Feijen, E., \& Laeven, L. (2008). Political Connections and Preferential Access to Finance: The Role of Campaign Contributions. Journal of Financial Economics, 88(3), 554580.

Core, J. E., Holthausen, R. W., \& Larcker, D. F. (1999). Corporate Governance, Chief Executive Office Compensation, and Firm Performance. Journal of Financial Economics, 51, 371-406.

Faccio, M., Masulis, R., \& McConnell, J. J. (2006). Political Connections and Corporate Bailouts. Journal of Finance, 61(6), 2597-2635.

Faccio, M. (2010). Differences between Politically Connected and Non-connected Firms: A Cross-Country Analysis. Financial Management, 39(3), 905-928.

FCCG. (2000). Malaysian Code on Corporate Governance 2000 (1 ed.). Kuala Lumpur: Ministry of Finance, Malaysia.

Fernando, C. S., Gatchev, V. A., \& Spindt, P. A. (2012). Institutional Ownership, Analyst Following and Share Prices. Journal of Banking and Finance, 36, 2175-2189.

Fraser, D. R., Zhang, H., \& Derashid, C. (2006). Capital Structure and Political Patronage: The Case of Malaysia. Journal of Banking \& Finance, 30(4), 1291-1308.

Goldman, E., Rocholl, J., \& So, J. (2013). Politically Connected Boards of Directors and the Allocation of Procurement Contracts. Review of Finance, 17(5), 1617-1648.

Gomez, E. T., \& Jomo, K. S. (1999). Malaysia's Political Economy: Politics, Patronage and Profits. Cambridge: Cambridge University Press.

Grier, P., \& J.Zychowicz, E. (1994). Institutional Investors, Corporate Discipline, and the Role of Debt. Journal of Economics and Business, 46, 1-11.

Gul, F. A. (2006). Auditors' Response to Political Connections and Cronyism in Malaysia. Journal of Accounting Research, 44(5), 931-963.

Gul, F. A., Fung, S. Y. K., \& Radhakhrishnan, S. (2010). Malaysian Government Election Losses, Political Connections and Equity Values: A Test of the Surviving Elite Hypothesis, JCAE Joint Symposium 2010. Seoul, Korea.

Hartzell, J. C., \& Starks, L. T. (2002). Institutional Investors and Executive Compensation. Journal of Finance, 58(6), 2351-2374.

Hawley, J. P., \& William, A. T. (1997). The Emergence of Fiduciary Capitalism. Corporate Governance: An International Review, 5(4), 206-213.

Healy, P. M., \& Palepu, K. G. (2001). Information Asymmetry, Corporate Disclosure, and the Capital Markets: A Review of the Empirical Disclosure Literature. Journal of Accounting and Economics, 31(1-3), 405-440. 
Hussain, S. (2000). Simultaneous Determination of UK Analyst Following and Institutional Ownership. Accounting and Business Research, 30(2), 111-124.

Jennings, W. W. (2005). Further Evidence on Institutional Ownership and Corporate Value. Advances in Financial Economics, 11, 167-207.

Jensen, M. C., \& Meckling, W. H. (1976). Theory of the Firm: Managerial Behavior, Agency Costs and Ownership Structure. Journal of Financial Economics, 3(4), 305-360.

Jiraporn, P., Kim, Y. S., \& Mathur, I. (2008). Does Corporate Diversification Exacerbate Or Mitigate Earnings Management?: An Empirical Analysis. International Review of Financial Analysis, 17(5), 1087-1109.

Johnson, S., \& Mitton, T. (2003). Cronyism and Capital Controls: Evidence from Malaysia. Journal of Financial Economics, 67, 351-382.

Karpoff, J. M. (2001). The Impact of Shareholder Activism on Target Companies: A Survey of Empirical Findings. University of Washington Working Paper Series.

Khawaja, A. I., \& Mian, A. (2005). Do Lenders Favor Politically Connected Firms? Rent provision in an Emerging Financial Market. The Quarterly Journal of Economics, 120(4), 1371-1411.

Lang, M. H., Lins, K. V., \& Miller, D. P. (2004). Concentrated Control, Analyst Following, and Valuation: Do Analysts Matter Most When Investors Are Protected Least? Journal of Accounting Research, 42(3), 589-623.

Lang, M. H., \& Lundholm, R. J. (1996). Corporate Disclosure Policy and Analyst Behavior. Accounting Review, 71(4), 467-492.

Leuz, C., \& Oberholzer-Gee, F. (2006). Political Relationships, Global Financing, And Corporate Transparency: Evidence from Indonesia. Journal of Financial Economics, 81(2), 411-439.

Lim, M.S., How, J., \& Verhoeven, P. (2014). Corporate Ownership, Corporate Governance Reform and Timeliness of Earnings: Malaysian Evidence. Journal of Contemporary Accounting \& Economics, 10(1), 32-45.

Mintchik, N., Stuerke, P., Wang, A., \& Zhang, G. (2010). Institutional Investor Preferences for Analyst Forecast Accuracy: Does Investment Strategy Matter?

Morck, R., Shleifer, A., \& Vishny, R. W. (1988). Management Ownership and Market Valuation: An Empirical Analysis. Journal of Financial Economics, 20, 293-315.

Moyer, R. C., Chatfield, R. E., \& Sisneros, P. M. (1989). Security Analyst Monitoring Activity: Agency Costs and Information Demands. Journal of Financial and Quantitative Analysis, December, 503-512. 
Norhashim, M., \& Abdul Aziz, K. (2005). Smart partnership or Cronyism? A Malaysian Perspective. The International Journal of Sociology and Social Policy, 25(8), 31-48.

North, D. (1990). Institutions, Institutional Change and Economic Performance. Cambridge: Cambridge University Press.

Olson, M. (1993). Dictatorship, Democracy, and Development. The American Political Science Review, 87(3), 567-576.

O'Brien, P. C., \& Bhushan, R. (1990). Analyst Following and Institutional Ownership. Journal of Accounting Research, 28(3), 55-76.

Riahi-Belkaoui, A. (2004). Politically-Connected Firms: Are They Connected To Earnings Opacity? Research in Accounting Regulation, 17(0), 25-38.

Selznick, P. (1949). TVA and the grass roots: A study of politics and organization (Vol. 3). University of California Pr.

Shleifer, A., \& Vishny, R. (1997). A Survey of Corporate Governance. Journal of Finance, 52(2), 737-775.

Shleifer, A., \& Vishny, R. (1994). Politicians and Firms. The Quarterly Journal of Economics, (November), 995-1025.

Short, H., \& Keasey, K. (1999). Managerial Ownership and the Performance of Firms: Evidence from the UK. Journal of Corporate Finance, 5(1), 79-101.

Starks, L. T. (2000). Corporate Governance and Institutional Investors: Implications For Latin America. Abante, 2(2), 161-181.

Stock, J. H., Wright, J. H., \& Yogo, M. (2002). A Survey of Weak Instruments and Weak Identification in Generalized Method of Moments. Journal of Business \& Economic Statistics, 20(4), 518-529.

Tan, H., Wang, S., \& Welker, M. (2011). Analyst Following and Forecast Accuracy after Mandated IFRS Adoptions. Journal of Accounting Research, 49(5), 1307-1357.

Wu, W., Wu, C., \& Rui, O. M. (2012). Ownership and the Value of Political Connections: Evidence from China. European Financial Management, 18(4), 695-729.

Yu, M. (2010). Analyst Forecast Properties, Analyst Following and Governance Disclosures: A Global Perspective. Journal of International Accounting, Auditing and Taxation, 19(1), 115. 


\section{Appendix A: Ownership of Share Capital in Limited Firms (1969-2008)}

\begin{tabular}{|c|c|c|c|c|c|c|c|c|c|c|}
\hline & 1969 & 1970 & 1975 & 1980 & 1985 & 1990 & 1995 & 2000 & 2004 & 2008 \\
\hline Total Bumiputras & 1.5 & 2.4 & 9.2 & 12.4 & 18.5 & 19.3 & 20.6 & 18.9 & 18.9 & 21.9 \\
\hline Individual & 1 & 1.6 & 3.6 & 4.3 & $n / a$ & 14.2 & 18.6 & 14.2 & 15 & $n / a$ \\
\hline Institutions & 0.5 & $n / a$ & $n / a$ & $n / a$ & $n / a$ & $n / a$ & $n / a$ & 3 & 2.2 & $n / a$ \\
\hline Trust Agencies & $n / a$ & 0.8 & 5.6 & 8.1 & $n / a$ & 5.1 & 2 & 1.7 & 1.7 & $n / a$ \\
\hline Total Non-Bumiputras & 34.3 & 34.3 & 37.5 & 40.1 & 49.5 & 46.8 & 43.4 & 41.3 & 40.6 & 36.7 \\
\hline Chinese & 22.8 & 27.2 & $n / a$ & $n / a$ & 48.2 & 45.5 & 40.9 & 38.9 & 39 & $n / a$ \\
\hline Indian & 0.9 & 1.1 & $n / a$ & $n / a$ & 0.9 & 1 & 1.5 & 1.5 & 1.2 & $n / a$ \\
\hline Others & 10.6 & 6 & $n / a$ & $n / a$ & 0.4 & 0.3 & 1 & 0.9 & 0.4 & $n / a$ \\
\hline Nominees & 2.1 & $\mathrm{n} / \mathrm{a}$ & $\mathrm{n} / \mathrm{a}$ & $\mathrm{n} / \mathrm{a}$ & 8 & 8.5 & 8.3 & 8.5 & 8 & $\mathrm{n} / \mathrm{a}$ \\
\hline Foreign & 62.1 & 63.3 & 53.3 & 47.5 & 24 & 25.4 & 27.7 & 31.3 & 32.5 & 41.4 \\
\hline Total & 100 & 100 & 100 & 100 & 100 & 100 & 100 & 100 & 100 & 100 \\
\hline
\end{tabular}

\section{Sources:}

Second Malaysia Plan, 1971-1975 (Malaysia, 1971, p. 40)

Third Malaysian Plan, 1976-1980 (Malaysia, 1976, p. 184)

Fourth Malaysian Plan, 1981-1985 (Malaysia, 1981, p. 61)

Sixth Malaysian Plan, 1990-1995 (Malaysia, 1990, p. 13)

Seventh Malaysian Plan, 1996-2000 (p.86)

Ninth Malaysian Plan, 2006-2010 (Malaysia, 2006, p. 356-57)

Tenth Malaysian Plan, 2011-2015 (Malaysia, 2011, p. 148) 


\begin{tabular}{rlll}
\hline & & & \\
1 & AFFIN HOLDINGS BHD & 35 & PADIBERAS NASIONAL BHD [S] \\
2 & AHMAD ZAKI RESOURCES BHD [S] & 36 & PETRONAS GAS BHD [S] \\
3 & BANDAR RAYA DEVELOPMENTS BHD [S] & 37 & PHARMANIAGA BHD [S] \\
4 & BERJAYA CORPORATION BHD & 38 & PROTON HOLDINGS BHD \\
5 & BERJAYA LAND BHD & 39 & RANHILL BHD [S] \\
6 & BERJAYA SPORTS TOTO BHD & 40 & SIME DARBY BHD [S] \\
7 & BIMB HOLDINGS BHD [S] & 41 & STAR PUBLICATIONS (M) BHD [S] \\
8 & BOUSTEAD HOLDINGS BHD & 42 & TANONG PUBLIC LIMITED COMPANY \\
9 & CAHYA MATA SARAWAK BHD [S] & 43 & TELEKOM MALAYSIA BHD [S] \\
10 & CYCLE \& CARRIAGE BINTANG BHD [S] & 44 & TENAGA NASIONAL BHD [S] \\
11 & DIGI.COM BHD [S] & 45 & TRANSMILE GROUP BHD [S] \\
12 & DRB-HICOM BHD & 46 & UMW HOLDINGS BHD [S] \\
13 & EDARAN OTOMOBIL NASIONAL BHD [S] & 47 & UNITED PLANTATIONS BHD [S] \\
14 & FABER GROUP BHD & 48 & YTL CORPORATION BHD [S] \\
15 & GOH BAN HUAT BHD [S] & 49 & YTL POWER INTERNATIONAL BHD [S] \\
16 & GOLDEN PLUS HOLDINGS BHD & 50 & ARAB-MALAYSIAN CORP \\
17 & GUOCOLAND (MALAYSIA) BHD & 51 & CAMERLIN GROUP \\
18 & HO HUP CONSTRUCTION COMPANY BHD [S] & 52 & CEMENT INDS.OF MALAYSIA \\
19 & HONG LEONG BANK BHD & 53 & COMMERCE ASSET-HLDG. \\
20 & HONG LEONG FINANCIAL GROUP BHD & 54 & GOLDEN HOPE PLTN. \\
21 & HONG LEONG INDUSTRIES BHD [S] & 55 & KEDAH CEMENT HOLDINGS BHD \\
22 & HUME INDUSTRIES (M) BHD [S] & 56 & KUMPULAN GUTHRIE \\
23 & IJM CORPORATION BHD [S] & 57 & LEISURE MANAGEMENT BHD \\
24 & JAYA TIASA HOLDINGS BHD [S] & 58 & MAGNUM \\
25 & LAND \& GENERAL BHD & 59 & MALAKOFF \\
26 & LANDMARKS BHD & 60 & MALAYSIA INTL.SHIPPING \\
27 & LION CORPORATION BHD [S] & 61 & METACORP \\
28 & MALAYAN BANKING BHD & 62 & METROPLEX \\
29 & MALAYSIA AIRPORT HOLDINGS BHD & 63 & NALURI \\
30 & MALAYSIAN AIRLINE SYSTEM BHD & 64 & NANYANG PRESS HDG. \\
31 & MTD CAPITAL BHD [S] & 65 & OYL INDUSTRIES \\
32 & MULPHA INTERNATIONAL BHD & 66 & PHILLEO ALLIED BHD \\
33 & MULTI-PURPOSE HOLDINGS BHD & 67 & THE NEW STRAITS TIMES PRESS (M) BHD \\
34 & NCB HOLDINGS BHD [S] & & \\
& & & \\
\hline \hline & & & \\
& & & \\
& &
\end{tabular}


Table 1: Descriptive Statistics (1999-2009)

\begin{tabular}{|c|c|c|c|c|c|c|}
\hline & Mean & Median & Maximum & Minimum & Std. Dev. & $\mathrm{N}$ \\
\hline \multicolumn{7}{|c|}{ Panel A: Experimental Variables } \\
\hline In(Analyst_Following) & 1.176 & 1.099 & 3.434 & 0.000 & 1.145 & 940 \\
\hline Analyst_Following & 6.217 & 3.000 & 31.000 & 1.000 & 7.185 & 940 \\
\hline Institutional_Ownership & 16.884 & 11.710 & 94.371 & 0.000 & 18.203 & 940 \\
\hline$E P F$ & 5.317 & 3.322 & 84.554 & 0.000 & 6.647 & 940 \\
\hline MSWG & 6.669 & 2.276 & 75.956 & 0.000 & 12.051 & 940 \\
\hline OTHERS & 4.898 & 0.738 & 74.464 & 0.000 & 11.931 & 940 \\
\hline Political_Connection & 0.282 & 0.000 & 1.000 & 0.000 & 0.450 & 940 \\
\hline \multicolumn{7}{|l|}{ Panel B: Control Variables } \\
\hline Size & 20.363 & 20.236 & 24.993 & 15.075 & 1.480 & 940 \\
\hline Size (RM'000) & 2433000 & 614100 & 71510000 & 3524 & 6251000 & 940 \\
\hline Forecast_Error & 0.678 & 0.168 & 20.023 & 0.000 & 1.781 & 940 \\
\hline$X \_$Listed & 0.063 & 0.000 & 1.000 & 0.000 & 0.243 & 940 \\
\hline 1/Price & 0.629 & 0.418 & 6.897 & 0.025 & 0.696 & 940 \\
\hline Board_Independence & 36.580 & 33.333 & 85.714 & 0.000 & 17.464 & 940 \\
\hline Duality & 0.352 & 1.000 & 1.000 & 0.000 & 0.478 & 940 \\
\hline Management_Ownership & 5.505 & 0.203 & 95.726 & 0.000 & 12.712 & 940 \\
\hline
\end{tabular}

Analyst_Following is the number of analyst following a firm. Institutional_Ownership is top five institutional investors' percentage shareholdings. EPF is percentage shareholdings by EPF. MSWG is the sum of the percentage shareholdings by LTH, PNB, LTAT, and SOCSO. OTHERS is the percentage shareholding of other institutional shareholders. Political_Connection takes the value of 1 if the firm is politically-connected and zero otherwise. Size is market capitalization. Forecast_Error is the absolute forecast error scaled by share price. $X \_$Listed takes the value of 1 if the firm is cross-listed and zero otherwise. 1/Price is the inverse of share price. Board_Independence is the proportion of independent directors on the board. Duality takes the value of 1 if the CEO and Chairman functions are held by the same person and zero otherwise. Management_Ownership is the percentage of direct managerial shareholding. 
Table 2: Correlation Matrix (1999-2009, n=940)

\begin{tabular}{|c|c|c|c|c|c|c|c|c|c|c|c|c|}
\hline & $\begin{array}{l}\text { In(Analyst_ } \\
\text { Following) }\end{array}$ & & $\begin{array}{l}\text { Institutional } \\
\text { OWwership }\end{array}$ & & $\begin{array}{r}\text { Political_ } \\
\text { Connection } \\
\end{array}$ & Size & $\begin{array}{r}\text { recast_ } \\
\text { Error }\end{array}$ & $X \_$Listed & 1/Price & $\begin{array}{c}\text { Board_ } \\
\text { Independence } \\
\end{array}$ & Duality & $\begin{array}{r}\text { Management } \\
\text { _Ownership }\end{array}$ \\
\hline In(Analyst_Following) & & & 0.234 & $* * *$ & $0.223 * * *$ & $0.583 * * *$ & $-0.311 * * *$ & $0.132 * * *$ & $-0.21 * * *$ & -0.013 & $0.064 *$ & $-0.134 * * *$ \\
\hline Institutional_Ownership & 0.192 & $* * *$ & & & $0.145 * * *$ & $0.229 * * *$ & -0.043 & $0.087 * * *$ & $-0.069 * *$ & -0.012 & 0.029 & $-0.172 * * *$ \\
\hline Political_Connection & 0.234 & $* * *$ & 0.234 & $* * *$ & & $0.395 * * *$ & -0.001 & $0.072 * *$ & $-0.132 * * *$ & $-0.089 * * *$ & $0.102 * * *$ & $-0.266 * * *$ \\
\hline Size & 0.579 & $* * *$ & 0.256 & $* * *$ & $0.393 * * *$ & & $-0.272 * * *$ & $0.201 * * *$ & $-0.376 * * *$ & -0.049 & $0.059 *$ & $-0.287 * * *$ \\
\hline Forecast_Error & -0.172 & $* * *$ & -0.038 & & -0.021 & $-0.158 * * *$ & & 0.031 & $0.114 * * *$ & $0.08 * *$ & 0.041 & 0 \\
\hline X_Listed & 0.139 & $* * *$ & 0.128 & $* * *$ & $0.072 * *$ & $0.252 * * *$ & 0.027 & & $-0.22 * * *$ & -0.009 & $-0.056 *$ & -0.043 \\
\hline 1/Price & -0.200 & $* * *$ & -0.088 & $* * *$ & $-0.119 * * *$ & $-0.344 * * *$ & 0.025 & $-0.108 * * *$ & & $0.064 * *$ & $-0.099 * * *$ & $0.072 * *$ \\
\hline Board_Independence & -0.017 & & 0.005 & & $-0.091 * * *$ & -0.040 & $0.078 * *$ & 0.010 & $0.064 * *$ & & $-0.085 * * *$ & -0.001 \\
\hline Duality & -0.062 & $*$ & -0.098 & $* * *$ & -0.102 & -0.060 & -0.049 & $0.056 *$ & $0.12 * * *$ & $0.072 * *$ & & $0.203 * * *$ \\
\hline Management_Ownership & -0.148 & $* * *$ & -0.116 & $* * *$ & $-0.184 * * *$ & $-0.237 * * *$ & $0.078 * *$ & -0.001 & 0.041 & 0.051 & $-0.134 * * *$ & \\
\hline
\end{tabular}

Pearson correlations are in italics. Analyst_Following is the number of analyst following a firm. Institutional_Ownership is top five institutional investors' percentage shareholdings. EPF is percentage shareholdings by EPF. MSWG is the sum of the percentage shareholdings by LTH, PNB, LTAT, and SOCSO. OTHERS is the percentage shareholding of other institutional shareholders. Political_Connection takes the value of 1 if the firm is politically-connected and zero otherwise. Size is market capitalization. Forecast Error is the absolute forecast error scaled by share price. $X \_$Listed takes the value of 1 if the firm is cross listed and zero otherwise. 1/Price is the inverse of share price. Board_Independence is the proportion of independent directors on the board. Duality takes the value of 1 if the CEO and Chairman positions are held by the same person and zero otherwise. Management_Ownership is the percentage of direct managerial shareholding. . *, ** and *** indicate significance at the 10 , 5 and 1 percent levels respectively. 
Table 3: Tests of Differences between Firms with High and Low Analyst Following

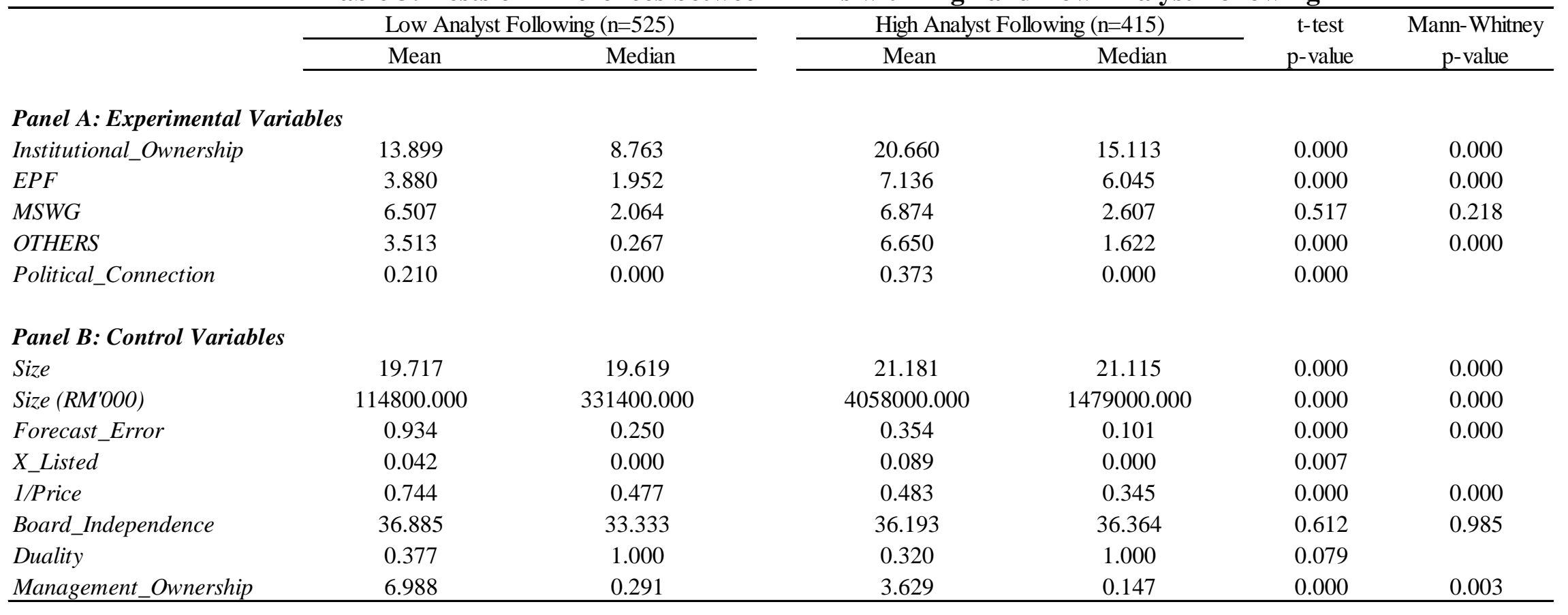

Firms are considered to have "high” (“low”) analyst following if Analyst_Following>median (Analyst_Following $\leq$ median). Institutional_Ownership is top five institutional investors' percentage shareholdings. EPF is percentage shareholdings by EPF. MSWG is the sum of the percentage shareholdings by LTH, PNB, LTAT, and SOCSO. OTHERS is the percentage shareholding of other institutional shareholders. Political_Connection takes the value of 1 if the firm is politically connected and zero otherwise. Size is market capitalization. Forecast_Error is the absolute forecast error scaled by share price. $X \_L i s t e d$ takes the value of 1 if the firm is cross-listed and zero otherwise. 1/Price is the inverse of share price. Board_Independence is the proportion of independent directors on the board. Duality takes the value of 1 if the CEO and Chairman positions are held by the same person and zero otherwise. Management_Ownership is the percentage of direct managerial shareholding. 
Table 4: Regressions Results for Analyst Following (1999-2009, n=940)

\begin{tabular}{|c|c|c|c|c|c|c|c|}
\hline & $\begin{array}{l}\text { Expected } \\
\text { Direction }\end{array}$ & $(1)$ & & $(2)$ & & $(3)$ & \\
\hline Constant & ? & $\begin{array}{c}-8.853 \\
(-11.405)\end{array}$ & $* * *$ & $\begin{array}{c}-8.978 \\
(-11.205)\end{array}$ & $* * *$ & $\begin{array}{c}-8.968 \\
(-11.122)\end{array}$ & $* * *$ \\
\hline Institutional_Ownership & + & & & $\begin{array}{c}0.004 \\
(1.713)\end{array}$ & * & $\begin{array}{c}0.004 \\
(1.166)\end{array}$ & \\
\hline Political_Connection & - & & & $\begin{array}{c}-0.091 \\
(-0.890)\end{array}$ & & $\begin{array}{c}-0.097 \\
(-0.759)\end{array}$ & \\
\hline Institutional_Ownership $\times$ Political_Connection & ? & & & & & $\begin{array}{c}0.000 \\
(0.082)\end{array}$ & \\
\hline Size & + & $\begin{array}{c}0.463 \\
(14.913)\end{array}$ & $* * *$ & $\begin{array}{c}0.464 \\
(14.124)\end{array}$ & $* * *$ & $\begin{array}{c}0.464 \\
(14.094)\end{array}$ & $* * *$ \\
\hline Forecast_Error & - & $\begin{array}{c}-0.063 \\
(-3.681)\end{array}$ & $* * *$ & $\begin{array}{c}-0.062 \\
(-3.605)\end{array}$ & $* * *$ & $\begin{array}{c}-0.062 \\
(-3.605)\end{array}$ & $* * *$ \\
\hline X_Listed & + & $\begin{array}{c}0.021 \\
(-0.113)\end{array}$ & & $\begin{array}{c}-0.008 \\
(-0.043)\end{array}$ & & $\begin{array}{c}-0.009 \\
(-0.047)\end{array}$ & \\
\hline 1/Price & + & $\begin{array}{c}0.089 \\
(1.661)\end{array}$ & * & $\begin{array}{c}0.091 \\
(1.704)\end{array}$ & * & $\begin{array}{c}0.091 \\
(1.696)\end{array}$ & * \\
\hline Board_Independence & + & $\begin{array}{c}0.002 \\
(1.049)\end{array}$ & & $\begin{array}{c}0.002 \\
(0.904)\end{array}$ & & $\begin{array}{c}0.002 \\
(0.907)\end{array}$ & \\
\hline Duality & - & $\begin{array}{c}-0.022 \\
(-0.279)\end{array}$ & & $\begin{array}{c}-0.014 \\
(-0.180)\end{array}$ & & $\begin{array}{c}-0.014 \\
(-0.179)\end{array}$ & \\
\hline Management_Ownership & - & $\begin{array}{c}-0.001 \\
(-0.231)\end{array}$ & & $\begin{array}{c}-0.001 \\
(-0.228)\end{array}$ & & $\begin{array}{c}-0.001 \\
(-0.230)\end{array}$ & \\
\hline Industry fixed & ? & Yes & & Yes & & Yes & \\
\hline Period fixed & ? & Yes & & Yes & & Yes & \\
\hline Adjusted $R^{2}$ & & 0.388 & & 0.391 & & 0.390 & \\
\hline F-statistic & & 22.268 & $* * *$ & 21.072 & $* * *$ & 20.371 & $* * *$ \\
\hline Period F-statistics & & 4.72 & $* * *$ & 4.496 & $* * *$ & 4.491 & $* * *$ \\
\hline
\end{tabular}

The dependent variable is the log of the number of analysts following a firm. Institutional_Ownership is top five institutional investors' percentage shareholdings. EPF is percentage shareholdings by EPF. MSWG is the sum of the percentage shareholdings by LTH, PNB, LTAT, and SOCSO. OTHERS is the percentage shareholding of other institutional shareholders. Political_Connection takes the value of 1 if the firm is politically-connected and zero otherwise. Size is market capitalization. Forecast_Error is the absolute forecast error scaled by share price. $X \_$Listed takes the value of 1 if the firm is cross listed and zero otherwise. 1/Price is the inverse of share price. Board_Independence is the proportion of independent directors on the board. Duality takes the value of 1 if the CEO and Chairman positions are held by the same person and zero otherwise. Management_Ownership is the percentage of direct managerial shareholding. *,** and *** indicate significance at the 10,5 , and 1 percent levels respectively. 
Table 5: Regressions Results for Analyst Following with Heterogeneous Institutional Investors $(1999-2009, n=940)$

\begin{tabular}{|c|c|c|c|c|c|c|c|c|c|c|c|c|c|}
\hline & $\begin{array}{l}\text { Expected } \\
\text { Direction }\end{array}$ & (1) & & $(2)$ & & (3) & & (4) & & (5) & & (6) & \\
\hline Constant & $?$ & $\begin{array}{c}-8.575 \\
(-10.818)\end{array}$ & $* * *$ & $\begin{array}{c}-8.549 \\
(-10.765)\end{array}$ & $* * *$ & $\begin{array}{c}-8.995 \\
(-11.152)\end{array}$ & *** & $\begin{array}{c}-8.988 \\
(-11.090)\end{array}$ & $* * *$ & $\begin{array}{c}-8.992 \\
(-11.172)\end{array}$ & $* * *$ & $\begin{array}{c}-8.902 \\
(-11.008)\end{array}$ & \\
\hline$E P F$ & + & $\begin{array}{c}0.026 \\
(4.646)\end{array}$ & $* * *$ & $\begin{array}{c}0.021 \\
(3.429)\end{array}$ & $* * *$ & & & & & & & & \\
\hline MSWG & + & & & & & $\begin{array}{c}0.000 \\
(-0.104)\end{array}$ & & $\begin{array}{c}-0.001 \\
(-0.133)\end{array}$ & & & & & \\
\hline OTHERS & + & & & & & & & & & $\begin{array}{c}0.001 \\
(0.328)\end{array}$ & & $\begin{array}{c}-0.002 \\
(-0.367)\end{array}$ & \\
\hline Political_Connection & - & $\begin{array}{c}-0.091 \\
(-0.925)\end{array}$ & & $\begin{array}{c}-0.206 \\
(-1.653)\end{array}$ & $*$ & $\begin{array}{c}-0.070 \\
(-0.692)\end{array}$ & & $\begin{array}{c}-0.074 \\
(-0.672)\end{array}$ & & $\begin{array}{c}-0.075 \\
(-0.733)\end{array}$ & & $\begin{array}{c}-0.099 \\
(-0.912)\end{array}$ & \\
\hline EPF $\times$ Political_Connection & $?$ & & & $\begin{array}{c}0.019 \\
(1.437)\end{array}$ & & & & & & & & & \\
\hline MSWG $\times$ Political_Connection & ? & & & & & & & $\begin{array}{c}0.001 \\
(0.082)\end{array}$ & & & & & \\
\hline OTHERS $\times$ Political_Connection & ? & & & & & & & & & & & $\begin{array}{c}0.005 \\
(0.693)\end{array}$ & \\
\hline Size & + & $\begin{array}{c}0.449 \\
(13.827)\end{array}$ & $* * *$ & $\begin{array}{c}0.448 \\
(13.808)\end{array}$ & $* * *$ & $\begin{array}{c}0.470 \\
(14.347)\end{array}$ & $* * *$ & $\begin{array}{c}0.470 \\
(14.314)\end{array}$ & $* * *$ & $\begin{array}{c}0.469 \\
(14.188)\end{array}$ & $* * *$ & $\begin{array}{c}0.467 \\
(14.122)\end{array}$ & $* * *$ \\
\hline Forecast_Error & - & $\begin{array}{c}-0.063 \\
(-3.763)\end{array}$ & $* * *$ & $\begin{array}{c}-0.062 \\
(-3.688)\end{array}$ & $* * *$ & $\begin{array}{c}-0.063 \\
(-3.653)\end{array}$ & $* * *$ & $\begin{array}{c}-0.063 \\
(-3.653)\end{array}$ & $* * *$ & $\begin{array}{c}-0.062 \\
(-3.638)\end{array}$ & $* * *$ & $\begin{array}{c}-0.063 \\
(-3.666)\end{array}$ & $* * *$ \\
\hline X_Listed & + & $\begin{array}{c}0.030 \\
(0.168)\end{array}$ & & $\begin{array}{c}0.006 \\
(0.036)\end{array}$ & & $\begin{array}{c}0.020 \\
(0.109)\end{array}$ & & $\begin{array}{c}0.019 \\
(0.107)\end{array}$ & & $\begin{array}{c}0.014 \\
(0.078)\end{array}$ & & $\begin{array}{c}0.018 \\
(0.097)\end{array}$ & \\
\hline 1/Price & + & $\begin{array}{c}0.091 \\
(1.719)\end{array}$ & $*$ & $\begin{array}{c}0.088 \\
(1.656)\end{array}$ & $*$ & $\begin{array}{c}0.092 \\
(1.713)\end{array}$ & $*$ & $\begin{array}{c}0.092 \\
(1.706)\end{array}$ & & $\begin{array}{c}0.092 \\
(1.709)\end{array}$ & $*$ & $\begin{array}{c}0.090 \\
(1.682)\end{array}$ & $*$ \\
\hline Board_Independence & + & $\begin{array}{c}0.002 \\
(0.865)\end{array}$ & & $\begin{array}{c}0.002 \\
(0.831)\end{array}$ & & $\begin{array}{c}0.002 \\
(0.996)\end{array}$ & & $\begin{array}{c}0.002 \\
(0.999)\end{array}$ & & $\begin{array}{c}0.002 \\
(0.985)\end{array}$ & & $\begin{array}{c}0.002 \\
(0.996)\end{array}$ & \\
\hline Duality & - & $\begin{array}{c}-0.005 \\
(-0.068)\end{array}$ & & $\begin{array}{c}-0.005 \\
(-0.068)\end{array}$ & & $\begin{array}{c}-0.026 \\
(-0.327)\end{array}$ & & $\begin{array}{c}-0.026 \\
(-0.325)\end{array}$ & & $\begin{array}{c}-0.024 \\
(-0.304)\end{array}$ & & $\begin{array}{c}-0.025 \\
(-0.311)\end{array}$ & \\
\hline Management_Ownership & - & $\begin{array}{c}0.000 \\
(0.012)\end{array}$ & & $\begin{array}{c}0.000 \\
(0.100)\end{array}$ & & $\begin{array}{c}-0.001 \\
(-0.312)\end{array}$ & & $\begin{array}{c}-0.001 \\
(-0.311)\end{array}$ & & $\begin{array}{c}-0.001 \\
(-0.306)\end{array}$ & & $\begin{array}{c}-0.001 \\
(-0.310)\end{array}$ & \\
\hline Industry Fixed & & Yes & & Yes & & Yes & & Yes & & Yes & & Yes & \\
\hline Period Fixed & & Yes & & Yes & & Yes & & Yes & & Yes & & Yes & \\
\hline Adjusted $R^{2}$ & & 0.407 & & 0.409 & & 0.387 & & 0.387 & & 0.387 & & 0.387 & \\
\hline F-statistic & & 22.506 & $* * *$ & 21.932 & $* * *$ & 20.790 & $* * *$ & 20.098 & $* * *$ & 20.800 & $* * *$ & 20.152 & *** \\
\hline Period F-statistics & & 4.756 & $* * *$ & 4.661 & $* * *$ & 4.780 & $* * *$ & 4.775 & $* * *$ & 4.755 & $* * *$ & 4.823 & $* * *$ \\
\hline
\end{tabular}

The dependent variable is the log of the number of analysts following a firm. Institutional_Ownership is top five institutional investors' percentage shareholdings. EPF is percentage shareholdings by EPF. MSWG is the sum of the percentage shareholdings by LTH, PNB, LTAT, and SOCSO. OTHERS is the percentage shareholding of other institutional shareholders. Political_Connection takes the value of 1 if the firm is politically-connected and zero otherwise. Size is market capitalization. Forecast_Error is the absolute forecast error scaled by share price. $X \_L i s t e d$ takes the value of 1 if the firm is cross-listed and zero otherwise. 1/Price is the inverse of share price. Board_Independence is the proportion of independent directors on the board. Duality takes the value of 1 if the CEO and Chairman positions are held by the same person and zero otherwise. Management_Ownership is the percentage of direct managerial shareholding. *, ** and *** indicate significance at the 10,5 and 1 percent levels respectively. 
Table 6: Two-Stage Least Squares (2SLS) Equations (1999-2009, n=940)

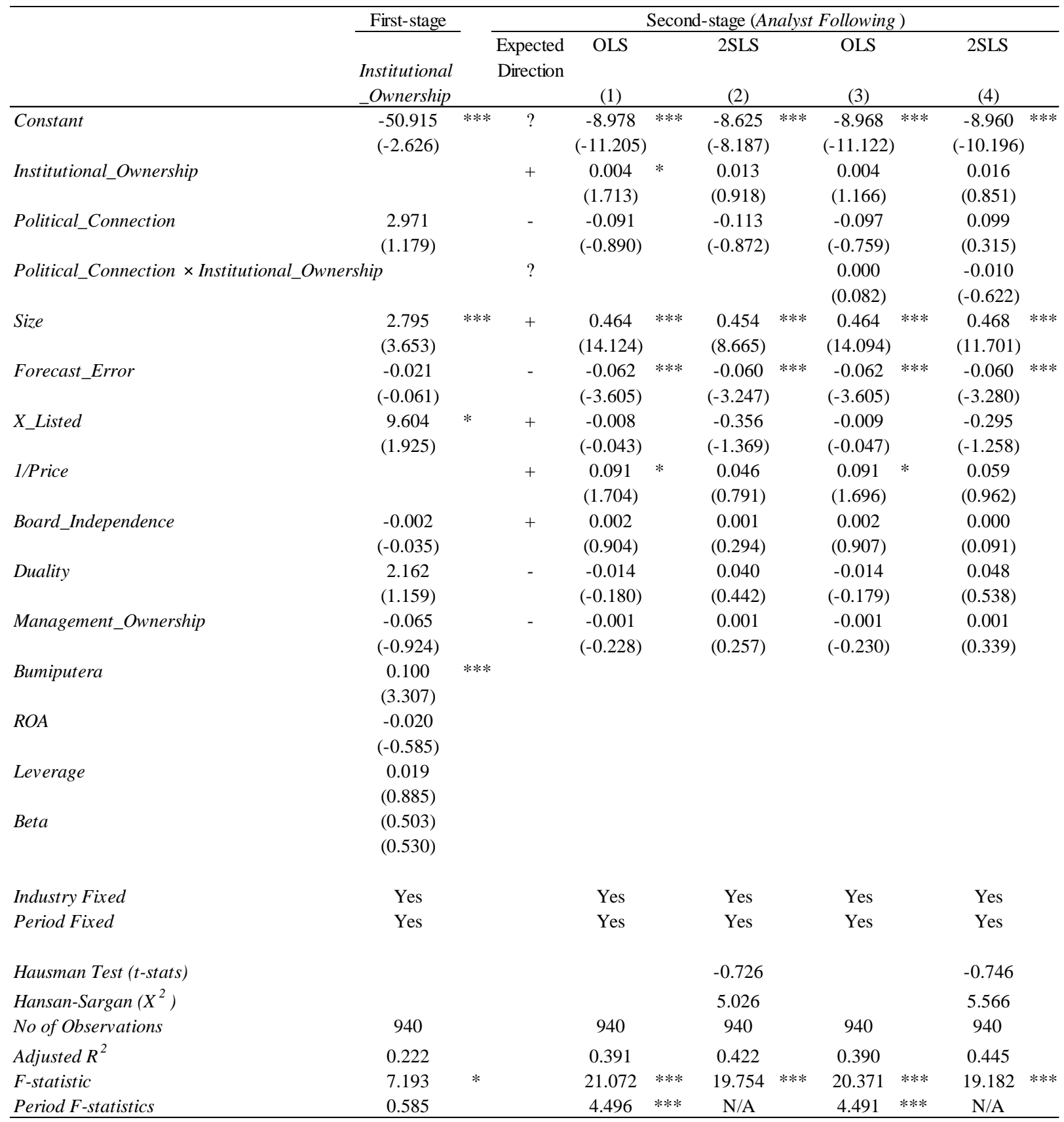

Institutional_Ownership is top five institutional investors' percentage shareholdings. Political_Connection takes the value of 1 if the firm is politically-connected and zero otherwise. Size is market capitalization. Forecast_Error is the absolute forecast error scaled by share price. $X \_$Listed takes the value of 1 if the firm is cross listed and zero otherwise. 1/Price is the inverse of share price. Board_Independence is the proportion of independent directors on the board. Duality takes the value of 1 if the CEO and Chairman positions are held by the same person and zero otherwise. Management_Ownership is the percentage of direct managerial shareholding. Bumiputera is the proportion of Bumiputera directors. ROA is the return on assets. Leverage is total debt to total assets. Beta is systematic risk, computed using the market model on the last 250 days of stock returns. *, ** and *** indicate significance at the 10, 5 and 1 percent levels respectively. 